\title{
Evaluation of Anion Influence on the Formation and Extraction Capacity of Ionic-Liquid-Based Aqueous Biphasic Systems
}

\author{
Sónia P. M. Ventura, ${ }^{\dagger}$ Catarina M. S. S. Neves, ${ }^{\dagger}$ Mara G. Freire, ${ }^{\dagger, \dagger}$ Isabel M. Marrucho, ${ }^{\dagger, \star}$ \\ João Oliveira, ${ }^{\S}$ and João A. P. Coutinho ${ }^{*, \dagger}$ \\ CICECO and CESAM, Departamento de Química, Universidade de Aveiro, 3810-193 Aveiro, Portugal and \\ Instituto de Tecnologia Química e Biológica, ITQB2, Universidade Nova de Lisboa, Av. República, \\ Apartado 127, 2780-901 Oeiras, Portugal
}

Received: April 9, 2009; Revised Manuscript Received: May 8, 2009

\begin{abstract}
Extractive fermentation using aqueous biphasic systems (ABS) is a promising separation process since it provides a nondenaturing environment for biomolecules and improves the stability of cells. Due to environmental concerns and toxicity issues related with common volatile organic solvents, ionic liquids (ILs), a new class of nonvolatile alternative solvents, are being currently investigated for extraction purposes. In this work, a wide range of imidazolium-based ILs was studied aiming at obtaining new insights regarding their ability toward the formation of ABS and their capacity to the extraction of biomolecules. On the basis of the IL cations 1-ethyl-3-methylimidazolium and 1-butyl-3-methylimidazolium, the IL anion influence on ABS formation was assessed through their combination with chloride, bromide, acetate, hydrogensulfate, methanesulfonate, methylsulfate, ethylsulfate, trifluomethanesulfonate, trifluoroacetate, and dicyanamide. Ternary phase diagrams (and respective tie-lines) formed by these hydrophilic ILs, water, and the inorganic salt $\mathrm{K}_{3} \mathrm{PO}_{4}$, were measured and are reported. The results indicate that the ability of an IL to induce ABS closely follows the decrease in the hydrogen bond accepting strength or the increase in the hydrogen bond acidity of the IL anion. In addition, the extraction capacity of the studied ABS was evaluated through their application to the extraction of an essential amino acid, L-tryptophan. It is shown that the partition coefficients obtained between the $\mathrm{IL}$ and the $\mathrm{K}_{3} \mathrm{PO}_{4}$-aqueous rich phases were substantially larger than those typically obtained with polymers-inorganic salts or polymers-polysaccharides aqueous systems.
\end{abstract}

\section{Introduction}

Fermentation processes are often inhibited by the accumulation of products in the bioreactor. The incorporation of a primary step in fermentation for product separation can enhance the product yield and facilitate the downstream processing. Among the different approaches for integrating reaction and product recovery steps in a biological process, the liquid-liquid extraction has shown a great potential. ${ }^{1,2}$ Several aspects of extractive fermentation, as well as general approaches for twophase bioreactor systems have been discussed in a recent review paper. ${ }^{3}$ The liquid-liquid extraction process presents additional advantages over conventional techniques, overcoming the lower efficiency in product recovery and the increased effluent treatment costs as a result of using a more concentrated feedstock. ${ }^{4}$ Liquid-liquid extraction techniques present higher capacity and better selectivity and allow the integration between recovery and purification. ${ }^{4}$

Before the Montreal Protocol, ${ }^{5}$ volatile organic compounds were commonly applied as extractive solvents because of their immiscibility with aqueous medium. ${ }^{6}$ After a reconsideration of the environmental impact of these processes, a new class of solvents, ionic liquids (ILs), has emerged in literature showing the capability of forming aqueous biphasic systems (ABS) in the presence of an inorganic salt. ${ }^{7}$ ILs negligible volatility, ${ }^{8,9}$

* To whom correspondence should be addressed. Tel.: +351 234401 507. Fax: +351234 370 084. E-mail: jcoutinho@ua.pt.

CICECO, Universidade de Aveiro.

* Universidade Nova de Lisboa.

${ }^{\S}$ CESAM, Universidade de Aveiro. low flammability, ${ }^{10}$ thermal stability, ${ }^{11,12}$ and, in some cases, biocompatibility contributed to their recognition as ambientfriendly media. ${ }^{13}$ In addition, the stability, activity, selectivity, and enantioselectivity of a particular enzyme is strongly dependent on the IL nature, and therefore, those properties can be finely tuned by correctly choosing the appropriate cation and/ or anion of the IL. Indeed, Park and Kazlauskas ${ }^{14}$ correlated the ILs aptitude for enzymes stabilization, activity, and selectivity with the ILs' polarity scale of Reichardt and hydrogen-bond basicity. Nevertheless, it should be kept in mind, that the relationship between ILs and enzymes is also dependent on the ions' nucleophilities, impurities, $\mathrm{pH}$, and medium composition, among others. In addition, Ulbert et al. ${ }^{15}$ corroborate those results finding that the higher the IL polarity is, the lower is the enzyme thermal stability. Highly hydrophilic ILs denaturate enzymes, either by ionic strength or specific binding to the protein surface. Increasing the opportunity for hydrogen-bonding with ILs increases the stability of enzymes in aqueous solutions.

Most works on ABS using ILs have been focused on the effect of several inorganic salts, ${ }^{7,16-18}$ or in the use of carbohydrates ${ }^{19-22}$ often based on the same IL forming system. The inorganic ion's influence seems to be well described by the Hofmeister series, ${ }^{23}$ but information on the effect of the IL ions on promoting ABS is particularly scarce. ${ }^{24,25}$ In a previous work, we studied the IL cation influence on ABS formation ability. ${ }^{25}$ Here, the IL anion influence was studied through their capability of forming $\mathrm{ABS}$, maintaining the inorganic salt $\left(\mathrm{K}_{3} \mathrm{PO}_{4}\right)$. Different phase diagrams for systems of hydrophilic ILs + $\mathrm{K}_{3} \mathrm{PO}_{4}+$ water, at $298 \mathrm{~K}$ and atmospheric pressure, were 
experimentally determined. The binodal curves were fitted to a three-parameter equation and the tie-lines were estimated using the Merchuck et al. ${ }^{26}$ approach.

Although there are a number of reports of IL-based ABS in the literature, few of these works report the extractive potential of such systems, and only solutes such as testosterone, epitestosterone, penicillin $\mathrm{G}$ and opium alkaloids have been considered. ${ }^{27-29}$ Thus, in this work, the investigated ILs for the phase diagrams study were further evaluated concerning their extractive capability for biomolecules, and for that purpose, Ltryptophan, an essential amino acid that could be produced in a fermentative medium, was selected as a model biomolecule.

\section{Experimental Section}

Materials. The ternary phase diagrams determination was performed by using an aqueous solution of $\mathrm{K}_{3} \mathrm{PO}_{4}(\geq 98$ wt \% pure from Sigma) and different aqueous solutions of ILs. The ILs studied were 1-ethyl-3-methylimidazolium chloride, [ $\left.\mathrm{C}_{2} \mathrm{mim}\right] \mathrm{Cl}$; 1-ethyl-3-methylimidazolium bromide, $\left[\mathrm{C}_{2} \mathrm{mim}\right]-$ [Br]; 1-ethyl-3-methylimidazolium acetate, $\left[\mathrm{C}_{2} \mathrm{mim}\right]\left[\mathrm{CH}_{3} \mathrm{CO}_{2}\right]$; 1-ethyl-3-methylimidazolium methylsulfate, $\left[\mathrm{C}_{2} \mathrm{mim}\right]\left[\mathrm{MeSO}_{4}\right]$; 1-ethyl-3-methylimidazolium ethylsulfate, $\left[\mathrm{C}_{2} \mathrm{mim}\right]\left[\mathrm{EtSO}_{4}\right]$; 1-ethyl-3-methylimidazolium methanesulfonate, $\left[\mathrm{C}_{2} \mathrm{mim}\right]\left[\mathrm{CH}_{3} \mathrm{SO}_{3}\right]$; 1-ethyl-3-methylimidazolium trifluoromethanesulfonate, $\left[\mathrm{C}_{2} \mathrm{mim}\right]-$ $\left[\mathrm{CF}_{3} \mathrm{SO}_{3}\right]$; 1-butyl-3-methylimidazolium chloride, $\left[\mathrm{C}_{4} \mathrm{mim}\right] \mathrm{Cl}$; 1-butyl-3-methylimidazolium bromide, [ $\left.\mathrm{C}_{4} \mathrm{mim}\right][\mathrm{Br}]$; 1-butyl3-methylimidazolium acetate, $\left[\mathrm{C}_{4} \mathrm{mim}\right]\left[\mathrm{CH}_{3} \mathrm{CO}_{2}\right]$; 1-butyl-3methylimidazolium dicyanamide, $\left[\mathrm{C}_{4} \mathrm{mim}\right]\left[\mathrm{N}(\mathrm{CN})_{2}\right]$; 1-butyl3-methylimidazolium methanesulfonate, $\left[\mathrm{C}_{4} \mathrm{mim}\right]\left[\mathrm{CH}_{3} \mathrm{SO}_{3}\right]$; 1-butyl-3-methylimidazolium hydrogensulfate, $\left[\mathrm{C}_{4} \mathrm{mim}\right]\left[\mathrm{HSO}_{4}\right]$; 1-butyl-3-methyl-imidazolium trifluoromethanesulfonate, [ $\left.\mathrm{C}_{4} \mathrm{mim}\right]-$ $\left[\mathrm{CF}_{3} \mathrm{SO}_{3}\right]$; and 1-butyl-3-methylimidazolium trifluoroacetate, $\left[\mathrm{C}_{4} \mathrm{mim}\right][\mathrm{TFA}]$. All the ILs, with the exception of $\left[\mathrm{C}_{4} \mathrm{mim}\right]-$ [TFA] that was acquired at Solchemar, were acquired at Iolitec and their structures are represented in Figure 1. To reduce the water and volatile compounds content to negligible values, ILs individual samples were dried under constant conditions at moderate vacuum and temperature, for a minimum of $48 \mathrm{~h}$. After this procedure, the purity of each ionic liquid was further checked by ${ }^{1} \mathrm{H},{ }^{13} \mathrm{C}$, and ${ }^{19} \mathrm{~F}$ and found to be superior to $99 \mathrm{wt}$ $\%$ for all samples. The water used was ultrapure water, double distilled, passed by a reverse osmosis system and further treated with a Milli-Q plus 185 water purification apparatus.

Experimental Procedure. Phase Diagrams and Tie-Lines. Aqueous solutions of $\mathrm{K}_{3} \mathrm{PO}_{4}$ at $40 \mathrm{wt} \%$ and aqueous solutions of different ILs at approximately $50 \mathrm{wt} \%$ were prepared and used for the determination of the binodal curves. The ternary system compositions were determined by the weight quantification of all components added within an uncertainty of $\pm 10^{-4}$ g. The detailed experimental procedure adopted and the respective validation is described in a previous work. ${ }^{25}$ The phase diagrams were determined through the cloud point titration method at $298 \mathrm{~K}( \pm 1 \mathrm{~K})$ and at atmospheric pressure. The tielines (TLs) were determined by a gravimetric method as proposed by Merchuck et al. ${ }^{26}$ Experimental binodal curves were correlated by least-squares regression using the nonlinear eq 1 :

$$
Y=A \exp \left[B X^{0.5}-C X^{3}\right]
$$

where $Y$ and $X$ are, respectively, the $\mathrm{IL}$ and $\mathrm{K}_{3} \mathrm{PO}_{4}$ mass fraction percentages, and $A, B$, and $C$ are constants obtained by data regression. ${ }^{26}$
For the TLs determination, a ternary mixture within the biphasic region was prepared and vigorously stirred. The equilibrium was attained by the separation of both phases after $12 \mathrm{~h}$, at $298 \mathrm{~K}$, using small ampules (ca. $10 \mathrm{~mL}$ ) especially designed for the purpose. Each individual TL was determined by the relationship between the initial mixture composition, the composition of the phases in equilibrium, and the overall system composition using the curve described by eq 1 . Further details can be found elsewhere in the literature. ${ }^{26}$

Partitioning of L-Tryptophan. A ternary mixture composition in the biphasic region was selected and used to evaluate the L-tryptophan partitioning at $298 \mathrm{~K}$. For that reason aqueous solutions of L-tryptophan with a concentration of approximately $0.78 \mathrm{~g} \cdot \mathrm{dm}^{-3}$ were prepared and used. The biphasic solution was left to equilibrate for $12 \mathrm{~h}$ to achieve a complete L-tryptophan partitioning between the two phases. ${ }^{25}$ The amino acid quantification, in both phases, was carried by UV spectroscopy using a SHIMADZU UV-1700, Pharma-Spec spectrometer, at a wavelength of $279 \mathrm{~nm} .{ }^{25}$ Possible interferences of both the inorganic salt and the IL with the analytical method were taken into account and found to be of no significance at the dilutions carried (the maximum peak of absorbance of imidazolium-based ILs is ca. $211 \mathrm{~nm}$ and, given the dilutions carried in all imidazolium-based IL-rich phases, there was no contribution of those compounds to the absorbance at $279 \mathrm{~nm}$, as experimentally verified). Three samples of each aqueous phase were precisely quantified. The partition coefficients of L-tryptophan, $K_{\text {Trp }}$, were determined as the ratio of the concentration of L-tryptophan in the IL and in the $\mathrm{K}_{3} \mathrm{PO}_{4}$ aqueous-rich phases and as described by:

$$
K_{\operatorname{Trp}}=\frac{[\mathrm{Trp}]_{\mathrm{IL}}}{[\operatorname{Trp}]_{\mathrm{K}_{3} \mathrm{PO}_{4}}}
$$

where $[\operatorname{Trp}]_{\mathrm{IL}}$ and $[\operatorname{Trp}]_{\mathrm{K}_{3} \mathrm{PO}_{4}}$ are the concentration of Ltryptophan in the IL and in the $\mathrm{K}_{3} \mathrm{PO}_{4}$ aqueous-rich phases, respectively.

In addition, both phases were weighted and the corresponding TLs obtained as previously described.

\section{Results and Discussion}

Phase Diagrams and Tie-Lines. The experimental phase diagrams at $298 \mathrm{~K}$ and at atmospheric pressure for each IL + $\mathrm{K}_{3} \mathrm{PO}_{4}+\mathrm{H}_{2} \mathrm{O}$ system are presented in Figures 2 and 3 (cf. Supporting Information with the experimental weight fraction data). Figure 2 shows the binodal curves for $\left[\mathrm{C}_{2} \mathrm{mim}\right][\mathrm{Cl}]$, $\left[\mathrm{C}_{2} \mathrm{mim}\right][\mathrm{Br}],\left[\mathrm{C}_{2} \mathrm{mim}\right]\left[\mathrm{CH}_{3} \mathrm{SO}_{3}\right],\left[\mathrm{C}_{2} \mathrm{mim}\right]\left[\mathrm{CH}_{3} \mathrm{CO}_{2}\right],\left[\mathrm{C}_{2} \mathrm{mim}\right]-$ $\left[\mathrm{MeSO}_{4}\right],\left[\mathrm{C}_{2} \mathrm{mim}\right]\left[\mathrm{EtSO}_{4}\right]$, and $\left[\mathrm{C}_{2} \mathrm{mim}\right]\left[\mathrm{CF}_{3} \mathrm{SO}_{3}\right]$. Figure 3 shows the binodal curves for $\left[\mathrm{C}_{4} \mathrm{mim}\right][\mathrm{Cl}],\left[\mathrm{C}_{4} \mathrm{mim}\right][\mathrm{Br}]$, $\left[\mathrm{C}_{4} \mathrm{mim}\right]\left[\mathrm{CH}_{3} \mathrm{SO}_{3}\right], \quad\left[\mathrm{C}_{4} \mathrm{mim}\right]\left[\mathrm{CH}_{3} \mathrm{CO}_{2}\right], \quad\left[\mathrm{C}_{4} \mathrm{mim}\right]\left[\mathrm{HSO}_{4}\right]$, $\left[\mathrm{C}_{4} \mathrm{mim}\right]\left[\mathrm{N}(\mathrm{CN})_{2}\right],\left[\mathrm{C}_{4} \mathrm{mim}\right][\mathrm{TFA}]$, and $\left[\mathrm{C}_{4} \mathrm{mim}\right]\left[\mathrm{CF}_{3} \mathrm{SO}_{3}\right]$. The results obtained show that the ability of ILs for $\mathrm{ABS}$ formation follows the order $\left[\mathrm{C}_{2} \mathrm{mim}\right]\left[\mathrm{CF}_{3} \mathrm{SO}_{3}\right]>\left[\mathrm{C}_{2} \mathrm{mim}\right]\left[\mathrm{EtSO}_{4}\right]>$ $\left[\mathrm{C}_{2} \mathrm{mim}\right]\left[\mathrm{MeSO}_{4}\right]>\left[\mathrm{C}_{2} \mathrm{mim}\right][\mathrm{Br}]>\left[\mathrm{C}_{2} \mathrm{mim}\right][\mathrm{Cl}] \cong$ $\left[\mathrm{C}_{2} \mathrm{mim}\right]\left[\mathrm{CH}_{3} \mathrm{CO}_{2}\right]>\left[\mathrm{C}_{2} \mathrm{mim}\right]\left[\mathrm{CH}_{3} \mathrm{SO}_{3}\right]$ and $\left[\mathrm{C}_{4} \mathrm{mim}\right]\left[\mathrm{CF}_{3} \mathrm{SO}_{3}\right]$ $>\left[\mathrm{C}_{4} \mathrm{mim}\right]\left[\mathrm{N}(\mathrm{CN})_{2}\right]>\left[\mathrm{C}_{4} \mathrm{mim}\right]\left[\mathrm{HSO}_{4}\right]>\left[\mathrm{C}_{4} \mathrm{mim}\right][\mathrm{TFA}]>$ $\left[\mathrm{C}_{4} \mathrm{mim}\right][\mathrm{Br}]>\left[\mathrm{C}_{4} \mathrm{mim}\right][\mathrm{Cl}] \cong\left[\mathrm{C}_{4} \mathrm{mim}\right]\left[\mathrm{CH}_{3} \mathrm{CO}_{2}\right] \cong$ $\left[\mathrm{C}_{4} \mathrm{mim}\right]\left[\mathrm{CH}_{3} \mathrm{SO}_{3}\right]$.

The solubility of a given solute in water is affected by the presence of an electrolyte. The decrease in solubility is known as salting-out effect while the increase is known as salting-in effect. The solubility of an electrolyte is also affected by the presence of a second electrolyte. ${ }^{30}$ Hence the water activity plays 
<smiles>CCn1cc[n+](C)c1</smiles>

i<smiles>CCn1cc[n+](C)c1</smiles>

iv

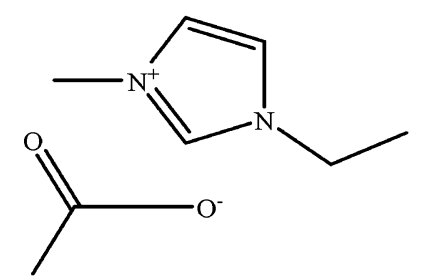

vii
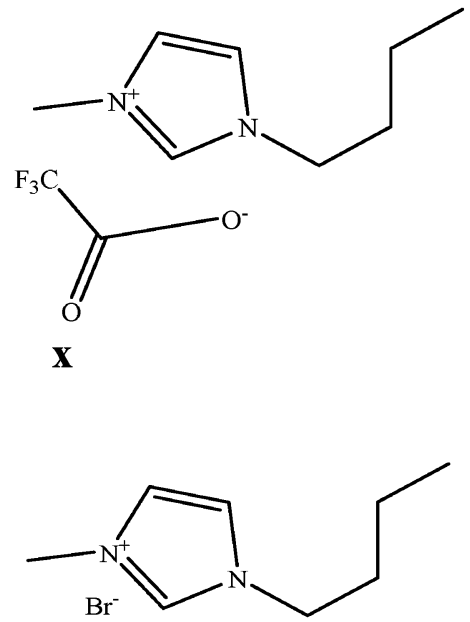

xiii<smiles>CCn1cc[n+](C)c1</smiles>

ii

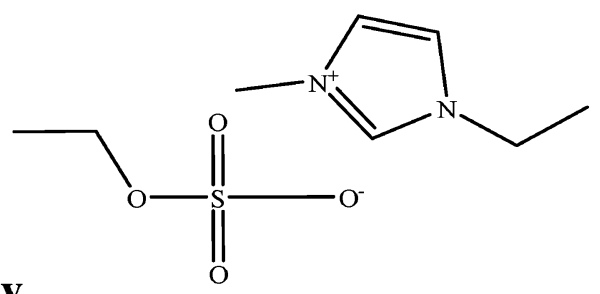<smiles>CCCCn1cc[n+](C)c1</smiles>

viii<smiles>CCCCn1cc[n+](C)c1</smiles>

$\mathbf{x i}$

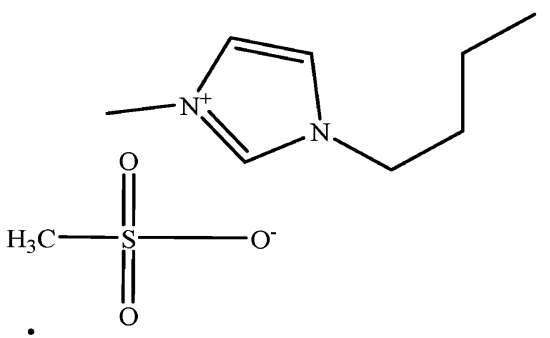

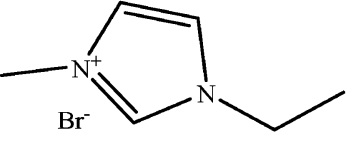

iii<smiles>CCn1cc[n+](C)c1</smiles>

vi<smiles>CCCCn1cc[n+](C)c1</smiles>

ix<smiles>CCCCn1cc[n+](C)c1</smiles>

xii

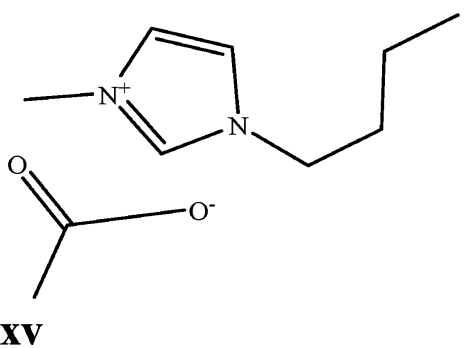

Figure 1. Chemical structure of the ILs studied: (i) $\left[\mathrm{C}_{2} \mathrm{mim}\right]\left[\mathrm{CF}_{3} \mathrm{SO}_{3}\right]$; (ii) $\left[\mathrm{C}_{2} \mathrm{mim}\right]\left[\mathrm{CH}_{3} \mathrm{SO}_{3}\right]$; (iii) $\left[\mathrm{C}_{2} \mathrm{mim}\right][\mathrm{Br}]$; (iv) $\left[\mathrm{C}_{2} \mathrm{mim}\right]\left[\mathrm{MeSO} \mathrm{C}_{4}\right]$; (v) $\left[\mathrm{C}_{2} \mathrm{mim}\right]\left[\mathrm{EtSO}_{4}\right]$; (vi) $\left[\mathrm{C}_{2} \mathrm{mim}\right][\mathrm{Cl}]$; (vii) $\left[\mathrm{C}_{2} \mathrm{mim}\right]\left[\mathrm{CH}_{3} \mathrm{CO}_{2}\right]$; (viii) $\left[\mathrm{C}_{4} \mathrm{mim}\right]\left[\mathrm{CF}_{3} \mathrm{SO}_{3}\right]$; (ix) $\left[\mathrm{C}_{4} \mathrm{mim}\right]\left[\mathrm{HSO}_{4}\right]$; (x) $\left[\mathrm{C}_{4} \mathrm{mim}\right][\mathrm{TFA}]$; (xi) $\left[\mathrm{C}_{4} \mathrm{mim}\right]\left[\mathrm{N}(\mathrm{CN})_{2}\right]$; (xii) $\left[\mathrm{C}_{4} \mathrm{mim}\right][\mathrm{Cl}]$; (xiii) $\left[\mathrm{C}_{4} \mathrm{mim}\right][\mathrm{Br}]$; (xiv) $\left[\mathrm{C}_{4} \mathrm{mim}\right]\left[\mathrm{CH}_{3} \mathrm{SO}_{3}\right]$; (xv) $\left[\mathrm{C}_{4} \mathrm{mim}\right]\left[\mathrm{CH}_{3} \mathrm{CO}_{2}\right]$.

a dominant role on the phase equilibria and on promoting ABS. Nevertheless, the addition of an inorganic salt to ionic aqueous systems leads to more complex phase equilibria than typical nonelectrolyte systems, and different mechanisms such as ion exchange and ion-pairing may arise. Bridges et al. ${ }^{18}$ have shown that there is in fact ion partitioning between both aqueous-rich phases, yet the overall deviations of the ions concentration present at any TL are small enough and can be not considered as a source of error.

Although the salting-out effect is usually explained based on the ordering of bulk water and on the ability of the ions to decrease the water structure by a simple hydration phenomena, recent works are converging upon to the idea that interactions between the IL ions and the inorganic salt ions may be present, and are mainly responsible for the salting-in or salting-out phenomena. ${ }^{31,32}$ Salting-out inducing ions act mainly through an entropic effect resulting from the formation of water-ion hydration complexes while the salting-in inducing ions directly interact with the hydrophobic moieties of the IL. ${ }^{31,32}$ The ions specific effects seem to be dominated by the ion-ion versus ion-water interactions though a complex interplay of factors, and not by the water-structure modification as classically accepted. ${ }^{23}$ Keeping in mind that $\mathrm{PO}_{4}{ }^{3-}$ is a high charge density ion (salting-out inducing ion), and that this ion was used in all 


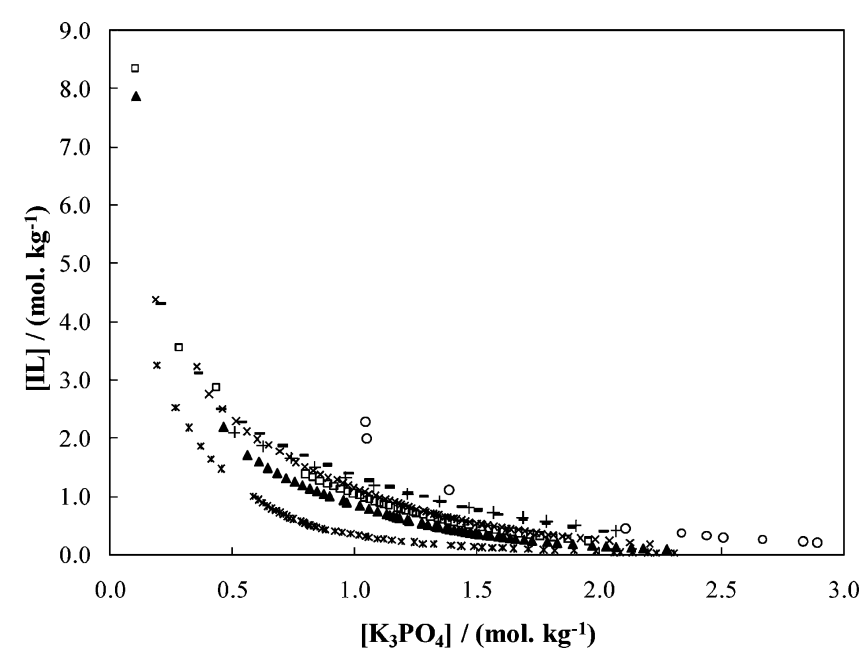

Figure 2. Phase diagrams for $\left[\mathrm{C}_{2} \mathrm{mim}\right]$-based ternary systems composed by IL $+\mathrm{K}_{3} \mathrm{PO}_{4}+\mathrm{H}_{2} \mathrm{O}$ at $298 \mathrm{~K}:(*)\left[\mathrm{C}_{2} \mathrm{mim}\right]\left[\mathrm{CF}_{3} \mathrm{SO}_{3}\right] ;(\boldsymbol{\Delta})$ $\left[\mathrm{C}_{2} \mathrm{mim}\right]\left[\mathrm{EtSO}_{4}\right] ;(+)\left[\mathrm{C}_{2} \mathrm{mim}\right]\left[\mathrm{CH}_{3} \mathrm{CO}_{2}\right] ;(\square)\left[\mathrm{C}_{2} \mathrm{mim}\right]\left[\mathrm{MeSO}_{4}\right] ;(\times)$ $\left[\mathrm{C}_{2} \mathrm{mim}\right][\mathrm{Br}] ;(-)\left[\mathrm{C}_{2} \mathrm{mim}\right][\mathrm{Cl}] ;(\mathrm{O})\left[\mathrm{C}_{2} \mathrm{mim}\right]\left[\mathrm{CH}_{3} \mathrm{SO}_{3}\right]$.

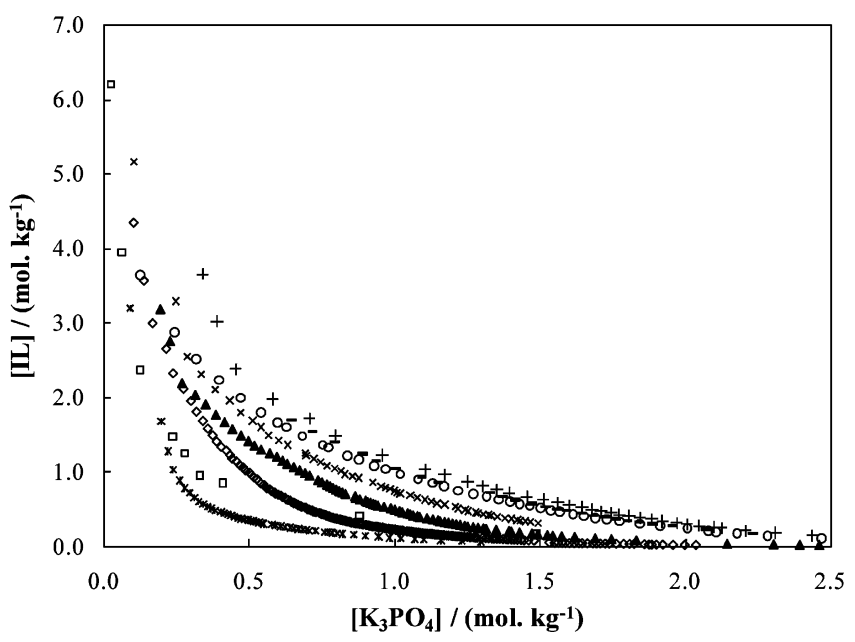

Figure 3. Phase diagrams for $\left[\mathrm{C}_{4} \mathrm{mim}\right]$-based ternary systems composed by $\mathrm{IL}+\mathrm{K}_{3} \mathrm{PO}_{4}+\mathrm{H}_{2} \mathrm{O}$ at $298 \mathrm{~K}$ : (*) $\left[\mathrm{C}_{4} \operatorname{mim}\right]\left[\mathrm{CF}_{3} \mathrm{SO}_{3}\right]$; $(\square)$ $\left[\mathrm{C}_{4} \mathrm{mim}\right]\left[\mathrm{HSO}_{4}\right] ;(\diamond)\left[\mathrm{C}_{4} \mathrm{mim}\right]\left[\mathrm{N}(\mathrm{CN})_{2}\right] ;(\Delta) \quad\left[\mathrm{C}_{4} \mathrm{mim}\right][\mathrm{TFA}] ;(\times)$ $\left[\mathrm{C}_{4} \mathrm{mim}\right][\mathrm{Br}] ;(\mathrm{O})\left[\mathrm{C}_{4} \mathrm{mim}\right]\left[\mathrm{CH}_{3} \mathrm{SO}_{3}\right] ;(-)\left[\mathrm{C}_{4} \mathrm{mim}\right][\mathrm{Cl}] ;(+)\left[\mathrm{C}_{4} \mathrm{mim}\right]-$ $\left[\mathrm{CH}_{3} \mathrm{CO}_{2}\right]$.

the ternary systems evaluated, it is possible to assess the IL anions inducing character. Considering the representations in Figures 2 and 3, the closer to the axis is located the binodal curve, the larger is the IL anion salting-in inducing behavior, that is, the lower is the density charge of the IL anions.

Studies regarding the ILs polarity provide useful information on the IL cations and anions solvation at the molecular level. The introduction of empirical solvent polarity scales based on solvent interactions with a reference solute has led to a rank on the compounds. ${ }^{33}$ Frequently used polarity scales, based on solvatochromic probes, are the Reichardt $E_{\mathrm{T}}(30)$ scale and the Kamlet-Taft's solvent parameters. ${ }^{34,35}$ In fact, the polarities of imidazolium-based ILs were found to be similar to that of short chain alcohols. ${ }^{36}$ A review regarding the polarity of ILs was presented recently by Reichardt. ${ }^{37}$ It should, nevertheless, be kept in mind that the solvent parameters are dependent on the molecule probe employed ${ }^{34}$ and are particularly relevant for these nanostructured fluids.

Table 1 reports the hydrogen-bond basicity $(\beta)$ and hydrogenbond acidity $(\alpha)$ of $\left[\mathrm{C}_{4} \mathrm{mim}\right]$-based ILs using the solvatochromic probe $\left[\mathrm{Fe}(\text { phen })_{2}(\mathrm{CN})_{2}\right] \mathrm{ClO}_{4} \cdot{ }^{38}$ The value of $\alpha$ decreases with
TABLE 1: Hydrogen-Bond Acidity $(\alpha)$ and Hydrogen-Bond Basicity $(\beta)$ of $\left[\mathrm{C}_{4} \mathrm{mim}\right]-$ Based ILs with the Solvatochromic Probe $\left[\mathrm{Fe}(\text { phen })_{2}(\mathrm{CN})_{2}\right] \mathrm{ClO}_{4}{ }^{38}$

\begin{tabular}{lcc}
\hline \multicolumn{1}{c}{$\mathrm{IL}$ anion } & $\alpha^{38}$ & $\beta^{38}$ \\
\hline$[\mathrm{Cl}]^{-}$ & 0.32 & 0.95 \\
{$[\mathrm{Br}]^{-}$} & 0.36 & 0.87 \\
{$\left[\mathrm{CH}_{3} \mathrm{CO}_{2}\right]^{-}$} & 0.36 & 0.85 \\
{$\left[\mathrm{CH}_{3} \mathrm{SO}_{3}\right]^{-}$} & 0.36 & 0.85 \\
{$\left[\mathrm{MeSO}_{4}\right]^{-}$} & 0.39 & 0.75 \\
{$[\mathrm{TFA}]^{-}$} & 0.43 & 0.74 \\
{$\left[\mathrm{~N}(\mathrm{CN})_{2}\right]^{-}$} & 0.44 & 0.64 \\
{$\left[\mathrm{CF}_{3} \mathrm{SO}_{3}\right]^{-}$} & 0.50 & 0.57 \\
{$\left[\mathrm{BF}_{4}\right]^{-}$} & 0.52 & 0.55 \\
{$\left[\mathrm{PF}_{6}\right]^{-}$} & 0.54 & 0.44 \\
{$\left[\left(\mathrm{CF}_{3} \mathrm{SO}_{2}\right)_{2} \mathrm{~N}\right]^{-}$} & 0.55 & 0.42
\end{tabular}

TABLE 2: Correlation Parameters Used in Equation 1 to Describe the Binodals at $298 \mathrm{~K}$

\begin{tabular}{cccc}
\hline $\mathrm{IL}+\mathrm{K}_{3} \mathrm{PO}_{4}+$ water system & $A$ & $B$ & $10^{5} \mathrm{C}$ \\
\hline$\left[\mathrm{C}_{2} \mathrm{mim}\right][\mathrm{Cl}]$ & 78.25 & -0.3389 & 2.697 \\
{$\left[\mathrm{C}_{2} \mathrm{mim}\right][\mathrm{Br}]$} & 85.60 & -0.3134 & 4.684 \\
{$\left[\mathrm{C}_{2} \mathrm{mim}\right]\left[\mathrm{CH}_{3} \mathrm{SO}_{3}\right]$} & 1476 & -0.9004 & 0.590 \\
{$\left[\mathrm{C}_{2} \mathrm{mim}\right]\left[\mathrm{CH}_{3} \mathrm{CO}_{2}\right]$} & 56.51 & -0.2346 & 3.022 \\
{$\left[\mathrm{C}_{2} \mathrm{mim}\right]\left[\mathrm{MeSO}_{4}\right]$} & 99.34 & -0.3374 & 4.693 \\
{$\left[\mathrm{C}_{2} \mathrm{mim}\right]\left[\mathrm{EtSO}_{4}\right]$} & 91.81 & -0.3320 & 5.740 \\
{$\left[\mathrm{C}_{2} \mathrm{mim}\right]\left[\mathrm{CF}_{3} \mathrm{SO}_{3}\right]$} & 149.2 & -0.5684 & 9.496 \\
{$\left[\mathrm{C}_{4} \mathrm{mim}\right][\mathrm{Cl}]$} & 72.64 & -0.3185 & 4.070 \\
{$\left[\mathrm{C}_{4} \mathrm{mim}\right][\mathrm{Br}]$} & 95.90 & -0.3912 & 5.197 \\
{$\left[\mathrm{C}_{2} \mathrm{mim}\right]\left[\mathrm{CH}_{3} \mathrm{SO}_{3}\right]$} & 70.24 & -0.2539 & 4.489 \\
{$\left[\mathrm{C}_{4} \mathrm{mim}\right]\left[\mathrm{CH}_{3} \mathrm{CO}_{2}\right]$} & 109.4 & -0.3832 & 3.126 \\
{$\left[\mathrm{C}_{4} \mathrm{mim}\right][\mathrm{HSO}$} & 94.08 & -0.6021 & 0.880 \\
{$\left[\mathrm{C}_{4} \mathrm{mim}\right]\left[\mathrm{N}_{4}\left(\mathrm{CN}_{2}\right]\right.$} & 190.7 & -0.8344 & 1.000 \\
{$\left[\mathrm{C}_{4} \mathrm{mim}\right][\mathrm{TFA}]$} & 92.30 & -0.3790 & 9.897 \\
{$\left[\mathrm{C}_{4} \mathrm{mim}\right]\left[\mathrm{CF}_{3} \mathrm{SO}_{3}\right]$} & 182.8 & -0.9676 & 1.000
\end{tabular}

increasing hydrogen-bond accepting strength of the IL anion. The ABS studied concern electrolyte solutions in aqueous medium and reflect the competition between the inorganic salt and the IL ions for the creation of water-ion hydration complexes. Therefore, the ability of a specific anion to be preferentially hydrated largely depends on the anions' hydrogenbonding accepting ability, and thus the ABS formation ability strongly depends on the anions' hydrogen-bonding basicity. This fact was observed for the ILs anions sequence studied in promoting ABS (Table 1). It is here obvious that the compilation of an accurate and extensive polarity scale of ILs is of main connotation, allowing the prediction of their behavior in aqueous systems, before carrying extensive experimental measurements of phase diagrams.

The binodal curves were fitted to the empirical correlation of Merchuk et al. ${ }^{26}$ (eq 1). The parameters for this equation were estimated by least-squares regression of the cloud point data and are reported in Table 2 . The ternary system composition used at the biphasic region and the TLs equations and respective tie-line lengths (TLLs) are reported in Table 3. As an example of the TLs measured in this work, Figure 4 shows TLs for the systems containing the ILs $\left[\mathrm{C}_{4} \mathrm{mim}\right][\mathrm{Br}]$ and $\left[\mathrm{C}_{4} \mathrm{mim}\right][\mathrm{TFA}]$. For the majority of the studied systems (and taking into consideration that for all the studied systems the top-rich phase is the IL-rich phase and the bottom phase is the $\mathrm{K}_{3} \mathrm{PO}_{4}$-rich phase), the IL concentration in the bottom phase is very small, and in some cases the IL is almost completely excluded from that phase. The opposite behavior is observed at the aqueous $\mathrm{K}_{3} \mathrm{PO}_{4}$ top phase. Usually, the total composition of the system has no significant effect upon the slope of the TLs, which implies that the TLs are parallel to each other, thus allowing the knowledge of the phase compositions for any given mixture. 
TABLE 3: Experimental Data for TLs and Respective TLLs at $298 \mathrm{~K}$

\begin{tabular}{|c|c|c|c|c|c|}
\hline \multirow[b]{2}{*}{ IL } & \multicolumn{2}{|c|}{$\begin{array}{l}\text { weight fraction } \\
\text { composition } \\
\text { (wt \%) } \\
\end{array}$} & \multicolumn{2}{|c|}{$\begin{array}{c}\text { TL equation } \\
\mathrm{IL}(\mathrm{wt} \%)=a+b \cdot \mathrm{K}_{3} \mathrm{PO}_{4} \\
(\mathrm{wt} \%)\end{array}$} & \multirow[b]{2}{*}{ TLL } \\
\hline & IL & $\mathrm{K}_{3} \mathrm{PO}_{4}$ & $a$ & $b$ & \\
\hline$\left[\mathrm{C}_{2} \mathrm{mim}\right][\mathrm{Br}]$ & 15.31 & 26.21 & 60.39 & -1.720 & 64.07 \\
\hline \multirow[t]{2}{*}[\mathrm{C}_{2}\operatorname{mim}]{$[\mathrm{Cl}]$} & 24.88 & 20.85 & 49.83 & -1.196 & 59.46 \\
\hline & 26.30 & 14.93 & 42.79 & -1.104 & 47.03 \\
\hline \multirow[t]{2}{*}[\mathrm{C}_{2}\mathrm{mim}]{$\left[\mathrm{CH}_{3} \mathrm{CO}_{2}\right]$} & 30.01 & 15.16 & 44.20 & -0.9356 & 62.04 \\
\hline & 24.94 & 14.96 & 38.31 & -0.8940 & 49.18 \\
\hline \multirow[t]{2}{*}[\mathrm{C}_{2}\mathrm{mim}]{$\left[\mathrm{MeSO}_{4}\right]$} & 20.31 & 24.94 & 61.58 & -1.655 & 65.19 \\
\hline & 33.23 & 12.81 & 58.56 & -1.976 & 47.46 \\
\hline \multirow[t]{3}{*}[\mathrm{C}_{2}\mathrm{mim}]{$\left[\mathrm{EtSO}_{4}\right]$} & 14.89 & 25.16 & 59.70 & -1.644 & 61.82 \\
\hline & 20.24 & 21.17 & 56.62 & -1.718 & 56.80 \\
\hline & 24.21 & 25.13 & 61.64 & -1.490 & 70.84 \\
\hline \multirow[t]{2}{*}[\mathrm{C}_{2}\mathrm{mim}]{$\left[\mathrm{CF}_{3} \mathrm{SO}_{3}\right]$} & 20.00 & 22.47 & 78.70 & -2.613 & 79.59 \\
\hline & 25.07 & 14.93 & 69.22 & -2.958 & 61.84 \\
\hline \multirow[t]{2}{*}[\mathrm{C}_{4}\operatorname{mim}]{$[\mathrm{Br}]$} & 21.09 & 29.55 & 69.95 & -1.653 & 24.54 \\
\hline & 24.41 & 19.90 & 58.90 & -1.733 & 62.34 \\
\hline \multirow[t]{3}{*}[\mathrm{C}_{4}\mathrm{mim}]{$\mathrm{Cl}$} & 15.75 & 22.67 & 42.27 & -1.170 & 45.97 \\
\hline & 17.69 & 21.54 & 42.91 & -1.171 & 47.67 \\
\hline & 21.36 & 23.04 & 51.40 & -1.304 & 61.20 \\
\hline \multirow[t]{2}{*}[\mathrm{C}_{4}\mathrm{mim}]{$\left[\mathrm{CH}_{3} \mathrm{SO}_{3}\right]$} & 30.33 & 14.86 & 49.34 & -1.280 & 56.20 \\
\hline & 25.03 & 14.96 & 43.66 & -1.245 & 38.91 \\
\hline \multirow[t]{3}{*}[\mathrm{C}_{4}\mathrm{mim}]{$\left[\mathrm{N}(\mathrm{CN})_{2}\right]$} & 19.89 & 22.65 & 69.98 & -2.211 & 71.44 \\
\hline & 24.86 & 15.86 & 64.42 & -2.446 & 61.84 \\
\hline & 15.19 & 20.12 & 64.97 & -2.528 & 61.87 \\
\hline \multirow[t]{2}{*}[\mathrm{C}_{4}\mathrm{mim}]{$[\mathrm{TFA}]$} & 15.24 & 20.39 & 59.58 & -2.174 & 59.03 \\
\hline & 19.90 & 24.65 & 70.35 & -2.047 & 76.77 \\
\hline \multirow[t]{2}{*}[\mathrm{C}_{4}\mathrm{mim}]{$\left[\mathrm{CF}_{3} \mathrm{SO}_{3}\right]$} & 25.00 & 15.35 & 69.78 & -2.917 & 68.83 \\
\hline & 25.08 & 14.96 & 69.68 & -2.982 & 68.37 \\
\hline
\end{tabular}

It was found that for short TLLs, the TLs are approximately parallel while for longer TLLs, the TLs slopes start to deviate. These deviations in the TLs slopes are in agreement with our previous work,,${ }^{25}$ as well as with literature, ${ }^{39}$ and it is related to the fact that the $\mathrm{K}_{3} \mathrm{PO}_{4}$-rich phase is increasingly free of IL at longer TLLs.

Partitioning of L-tryptophan. Amino acids are the constituents of proteins. The partitioning studies of such biomolecules in ABS have great significance not only regarding their purification, but also aiming at extending them to proteins and enzymes. The success of the extractive potential of ABS depends on the ability to manipulate phase properties to obtain the appropriate partition coefficients and selectivity for the biomolecule of interest. There are several approaches to manipulate a particular solute partitioning: (i) adjust the system by applying different salts and/or ILs controlling thus the solute's affinity; (ii) change the system composition by changing either the concentration of salt and IL; (iii) introduction of additional cosolvents, antisolvents, or amphiphilic structures to the overall system.

The mixture compositions selected for the amino acid partitioning, for each particular system, are described in Table 4. In addition, the respective TLs and TLLs are also included in Table 4. The graphical representation of the TLs corresponding to the ternary composition used for the L-tryptophan partitioning is presented in Figure 4 (concomitantly with the TLs obtained when no amino acid is present). It is clear that the addition of amino acid (at least in the concentrations used) has no significant influence on the TLs and TLLs obtained. The concentration of L-tryptophan is small enough to be irrelevant compared with the total and each individual aqueous phases mass composition. Thus the TLs and TLLs presented in Table 4 could be considered as additional phase equilibrium TLs of each individual ternary system.
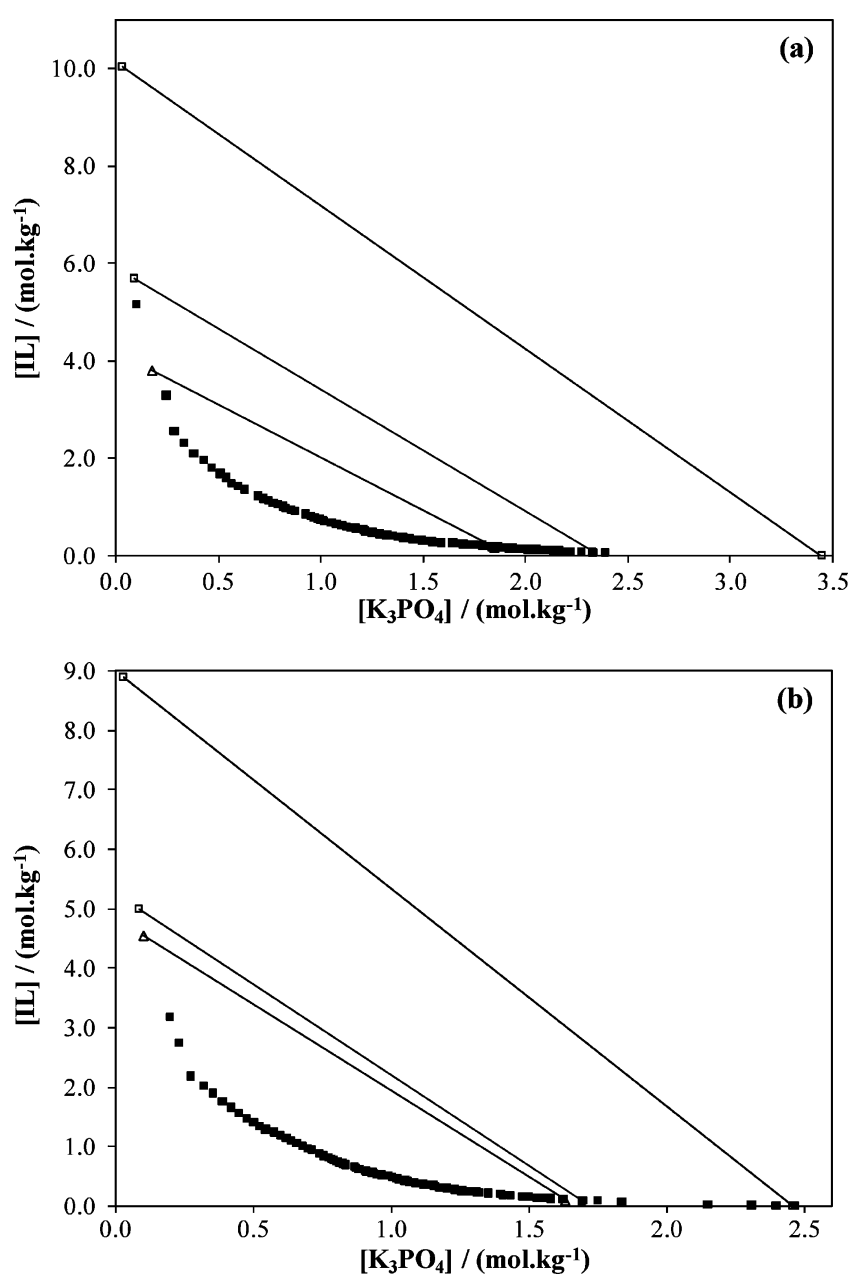

Figure 4. (a) Phase diagram for the $\left[\mathrm{C}_{4} \mathrm{mim}\right][\mathrm{Br}]+\mathrm{K}_{3} \mathrm{PO}_{4}+$ water ternary system at $298 \mathrm{~K}$ and (b) phase diagram for the [ $\left.\mathrm{C}_{4} \mathrm{mim}\right]$ [TFA] $+\mathrm{K}_{3} \mathrm{PO}_{4}+$ water ternary system at $298 \mathrm{~K}$ : (ם) binodal curve data; $(\square)$ TL data; $(\Delta)$ extraction TL data.

To successfully apply ILs as extraction media in ABS, the factor governing the partitioning of biomolecules between the two equilibrium aqueous-rich phases must be understood. The partition coefficients give the partition behavior of Ltryptophan between the IL and the $\mathrm{K}_{3} \mathrm{PO}_{4}$-rich phases. The higher the $K_{\operatorname{Trp}}$ the higher the tendency for the solute to migrate to the IL-rich phase. Among the different interactions between molecules, hydrophobic interactions play a key role in the behavior of proteins in solution. ${ }^{40}$ Therefore, the relative hydrophobicity of ILs can provide some insights regarding their ability to extract amino acids and proteins. Moreover, the soluteIL interactions are likely to involve van der Waals forces, electrostatic interactions, hydrogen-bonding, and $\pi \cdots \pi$ stacking between the imidazolium ring and the aromatic ring of Ltryptophan. Indeed, $\pi \cdots \pi$ stacking between imidazolium and benzene molecules has been reported previously. ${ }^{41}$

For the ternary system compositions described in Table 4 (approximately $25 \mathrm{wt} \%$ of IL and 15 wt $\%$ of $\mathrm{K}_{3} \mathrm{PO}_{4}$ ), the partition coefficients of L-tryptophan follow the rank $\left[\mathrm{C}_{2} \operatorname{mim}\right][\mathrm{Cl}]>\left[\mathrm{C}_{2} \mathrm{mim}\right]\left[\mathrm{CF}_{3} \mathrm{SO}_{3}\right] \cong\left[\mathrm{C}_{2} \mathrm{mim}\right]\left[\mathrm{CH}_{3} \mathrm{CO}_{2}\right]>$ $\left[\mathrm{C}_{2} \mathrm{mim}\right]\left[\mathrm{EtSO}_{4}\right] \cong\left[\mathrm{C}_{2} \mathrm{mim}\right]\left[\mathrm{MeSO}_{4}\right]$ and $\left[\mathrm{C}_{4} \mathrm{mim}\right]\left[\mathrm{N}(\mathrm{CN})_{2}\right]$ $>\left[\mathrm{C}_{4} \mathrm{mim}\right][\mathrm{Cl}] \cong\left[\mathrm{C}_{4} \mathrm{mim}\right][\mathrm{TFA}] \cong\left[\mathrm{C}_{4} \mathrm{mim}\right][\mathrm{Br}]>\left[\mathrm{C}_{4} \mathrm{mim}\right]-$ $\left[\mathrm{CF}_{3} \mathrm{SO}_{3}\right]>\left[\mathrm{C}_{4} \mathrm{mim}\right]\left[\mathrm{CH}_{3} \mathrm{SO}_{3}\right]$. L-tryptophan partitions preferentially for IL-rich phases composed by halogenated ions such as $[\mathrm{Cl}]^{-}$or $[\mathrm{Br}]^{-}$or to the most hydrophobic anions, that is, anions with higher hydrogen bonding accepting strength $(\beta)$, such as $\left[\mathrm{N}(\mathrm{CN})_{2}\right]$ and fluoride-based anions. 
TABLE 4: Weight Fraction Composition and Partition Coefficients of L-Tryptophan in IL-Based ABS Systems at 298 K

\begin{tabular}{|c|c|c|c|c|c|c|}
\hline \multirow[b]{2}{*}{ IL } & \multicolumn{2}{|c|}{$\begin{array}{l}\text { weight fraction } \\
\text { composition } \\
\text { (wt \%) }\end{array}$} & \multicolumn{2}{|c|}{$\begin{array}{c}\text { TL equation } \\
\mathrm{IL}(\mathrm{wt} \%)=a+b \mathrm{~K}_{3} \mathrm{PO}_{4} \\
(\mathrm{wt} \%)\end{array}$} & \multirow[b]{2}{*}{ TLL } & \multirow[b]{2}{*}{$K_{\text {Trp }}$} \\
\hline & IL & $\mathrm{K}_{3} \mathrm{PO}_{4}$ & $a$ & $b$ & & \\
\hline$\left[\mathrm{C}_{2} \operatorname{mim}\right][\mathrm{Cl}]$ & 25.90 & 14.90 & 42.36 & -1.105 & 45.73 & $59.2 \pm 0.4$ \\
\hline$\left[\mathrm{C}_{2} \mathrm{mim}\right]\left[\mathrm{CH}_{3} \mathrm{CO}_{2}\right]$ & 24.94 & 14.96 & 38.31 & -0.8940 & 49.18 & $16.4 \pm 0.8$ \\
\hline$\left[\mathrm{C}_{2} \mathrm{mim}\right]\left[\mathrm{MeSO}_{4}\right]$ & 24.98 & 14.94 & 49.80 & -1.661 & 28.89 & $4.47 \pm 0.9$ \\
\hline$\left[\mathrm{C}_{2} \mathrm{mim}\right]\left[\mathrm{EtSO}_{4}\right]$ & 24.97 & 15.06 & 48.90 & -1.589 & 39.86 & $5.96 \pm 0.5$ \\
\hline$\left[\mathrm{C}_{4} \mathrm{mim}\right][\mathrm{Br}]$ & 25.82 & 15.17 & 51.60 & -1.699 & 48.36 & $35.6 \pm 0.8$ \\
\hline$\left[\mathrm{C}_{4} \mathrm{mim}\right]\left[\mathrm{CH}_{3} \mathrm{SO}_{3}\right]$ & 25.03 & 14.96 & 43.66 & -1.245 & 38.91 & $10.4 \pm 0.4$ \\
\hline$\left[\mathrm{C}_{4} \mathrm{mim}\right]\left[\mathrm{N}(\mathrm{CN})_{2}\right]$ & 24.40 & 16.82 & 67.35 & -2.553 & 64.90 & $45.1 \pm 0.9$ \\
\hline$\left[\mathrm{C}_{4} \mathrm{mim}\right][\mathrm{TFA}]$ & 25.13 & 15.22 & 57.90 & -2.154 & 56.16 & $36.1 \pm 0.7$ \\
\hline$\left[\mathrm{C}_{4} \mathrm{mim}\right]\left[\mathrm{CF}_{3} \mathrm{SO}_{3}\right]$ & 25.08 & 16.18 & 76.12 & -3.154 & 75.39 & $16.6 \pm 0.6$ \\
\hline
\end{tabular}

Indeed, these partition coefficients seem to closely follow the Hofmeister series. ${ }^{42}$ Salting-in inducing IL ions tend to increase the solute partition coefficient while the salting-out inducing IL ions tend to decrease it.

Attending to the results of our previous work, ${ }^{25}$ the influence of the IL imidazolium-based cation on the extraction capacity of $\mathrm{ABS}$ seems to be more important than the influence of the anion. Indeed, in the study of the cation influence the $K_{\operatorname{Trp}}$ was found to vary between 10 and 120 (at approximately the same mass fraction compositions of IL plus inorganic salt). The presence of benzyl groups and double bounds at the imidazolium side alkyl chain increased substantially such partition coefficients. ${ }^{25}$ Besides the $\pi \cdots \pi$ stacking, the possibility of solute-IL hydrogen-bonding seems to rule the partition behavior. Nonetheless, it should be kept in mind that solutes other than L-tryptophan should be explored in order to develop a full picture of the extractive potential of IL-based ABS.

The partition coefficients obtained in this work for Ltryptophan are substantially higher than those observed in conventional polymer-polysaccharide $\left(K_{\operatorname{Trp}} \cong 1\right)$ or polymerinorganic salts $\left(K_{\operatorname{Trp}} \cong 1-7\right)$ reported in literature. ${ }^{43,44}$ These results indicate that ILs are a novel option for the purification and separation of biomolecules with much larger partition coefficients than conventional ABS. Moreover, ILs can be finetuned in order to manipulate such partition coefficients. At this stage, further academic and industrial investigations on the topic of the ILs potential as extraction media, as well as their toxicity and biodegradability issues, are vital requisites.

\section{Conclusions}

Ionic liquids have been shown to be able to induce aqueous phases separation in the presence of inorganic salts and thus to form ABS. Therefore, new experimental equilibrium data for the compositions of coexisting phases of $\mathrm{ABS}$ involving hydrophilic imidazolium-based ILs $+\mathrm{K}_{3} \mathrm{PO}_{4}+\mathrm{H}_{2} \mathrm{O}$, at the same conditions of temperature and pressure $(298 \mathrm{~K}$ and atmospheric pressure), were studied and reported.

The ability of imidazolium-based ILs for aqueous phase separation was shown to closely follow the hydrogen bond accepting strength decrease of the anions composing the IL. The results indicate that IL-based ABS can be obtained over a large range of concentrations of both the inorganic salt and the IL, and such systems can be finely tuned by the adjustment of the IL anion.

The capacity of the IL-based ABS as prospective extraction media in biotechnological processes was demonstrated by the high partition coefficients obtained for one essential amino acid:
L-tryptophan. The values obtained are substantially larger than those observed with conventional polymer-based ABS and further studies regarding ILs aiming at obtaining a complete perspective of the molecular interactions controlling the solutes partition behavior is of utmost importance.

Acknowledgment. The authors are grateful for financial support from Fundação para a Ciência e a Tecnologia for the project PTDC/EQU-FTT/65252/2006 and Ph.D. grants SFRH/ BD/37830/2007 of Sónia P. M. Ventura and postdoctoral grant SFRH/BPD/41781/2007 of Mara G. Freire.

Supporting Information Available: Tables of additional data for the IL systems. This material is available free of charge via the Internet at http://pubs.acs.org.

\section{References and Notes} 280.

(1) Kwon, Y. J.; Kaul, R.; Mattison, B. Biotechnol. Bioeng. 1996, 50,

(2) Lee, Y. H.; Chang, H. N. J. Ferment. Bioeng. 1990, 69, 89.

(3) Malinowski, J. J. Biotechnol. Adv. 2001, 19, 525.

(4) Daugulis, A. J.; Axford, D. B.; Ciszek, B.; Malinowski, J. J. Biotechnol. Lett. 1994, 16, 637.

(5) Martínez-Aragón, M.; Burghoff, S.; Goetheer, E. L: V.; de Haan, A. B. Sep. Purif. Technol. 2009, 65, 65-72.

(6) Rydberg, J.; Musikas, C.; Choppin, G. R. Principles and Practices of Solvent Extraction; Marcel Dekker, Inc.: New York, 1992.

(7) Gutowski, K. E.; Broker, G. A.; Willauer, H. D.; Huddleston, G. J.; Swatloski, R. P.; Holbrey, J. D.; Rogers, R. D. J. Am. Chem. Soc. 2003, 125,6632 .

(8) Earle, M. J.; Esperança, J. M. S. S.; Gilea, M. A.; Lopes, J. N. C.; Rebelo, L. P. N.; Magee, J. W.; Seddon, K. R.; Widegren, J. A. Nature 2006, $439,831$.

(9) Rebelo, L. P. N.; Lopes, J. N. C.; Esperança, J. M. S. S.; Filipe, E. J. Phys. Chem. B 2005, 109, 6040.

(10) Smiglak, M.; Reichert, W. M.; Holbrey, J. D.; Wilkes, J. S.; Sun, L.; Thrasher, J. S.; Kirichenko, K.; Singh, S.; Katritzky, A. R.; Rogers, R. D. Chem. Commun. 2006, 24, 2554.

(11) Baranyai, K. J.; Deacon, G. B.; MacFarlane, D. R.; Pringle, J. M.; Scott, J. L. Aust. J. Chem. 2004, 57, 145.

(12) Domanska, U. Thermochim. Acta 2006, 448, 19.

(13) Visak, Z. P.; Lopes, J. N. C.; Rebelo, L. P. N. Monatsh. Chem. 2007, 138, 1153.

(14) Park, S.; Kazlauskas, R. J. Curr. Opin. Biotechnol. 2003, 14, 432. (15) Ulbert, O.; Bélafi-Bakó, K.; Tonova, K.; Gubicza, L. Biocatal. Biotransform. 2005, 23, 177.

(16) Pei, Y.; Wang, J.; Liu, L-.; Wu, K.; Zhao, Y. J. Chem. Eng. Data 2007, 52, 2026.

(17) Zafarani-Moattar, M. T.; Hamzehzadeh, S. J. Chem. Eng. Data 2007, 52, 1686.

(18) Bridges, N. J.; Gutowski, K. E.; Rogers, R. D. Green Chem. 2007, 9, 177.

(19) Wu, B.; Zhang, Y.; Wang, H. J. Phys. Chem. B 2008, 112, 6426.

(20) Wu, B.; Zhang, Y.; Wang, H.; Yang, L. J. Phys. Chem. B 2008,

$112,13163$. 
(21) Wu, B.; Zhang, Y. M.; Wang, H. P. J. Chem. Eng. Data 2008, 53 , 983.

(22) Zhang, Y.; Zhang, S.; Chen, Y.; Zhang, J. Fluid Phase Equilib. 2007, 257, 173.

(23) Hofmeister, F. Arch. Exp. Pathol. Pharmakol. 1888, XXV, 1.

(24) Najdanovic-Visak, V.; Canongia Lopes, J. N.; Visak, Z. P.; Trindade, J.; Rebelo, L. P. N. Int. J. Mol. Sci. 2007, 8, 736.

(25) Neves, C. M. S. S.; Ventura, S. P. M.; Freire, M. G.; Marrucho,

I. M.; Coutinho, J. A. P. J. Phys. Chem. B 2009, 113, 5194.

(26) Merchuk, J. C.; Andrews, B. A.; Asenjo, J. A. J. Chromatogr. B 1998, 711, 285.

(27) He, C.; Li, S.; Liu, H.; Li, K.; Liu, F. J. Chromatogr. A 2005, 1082,143

(28) Li, S.; He, C.; Liu, H.; Li, K.; Liu, F. J. Chromatogr. B 2005, 826, 58. (29) Liu, Q.; Yu, J.; Li, W.; Hu, X.; Xia, H.; Liu, H.; Yang, P. Sep. Sci. Technol. 2006, 41, 2849.

(30) Mateolli, E.; Mansoori, G. A. Fluctuation Theory of Mixtures; Taylor \& Francis: New York, 1990.

(31) Freire, M. G.; Carvalho, P. J.; Silva, A. M. S.; Santos, L. M. N. B. F.; Rebelo, L. P. N.; Marrucho, I. M.; Coutinho, J. A. P. J. Phys. Chem. B 2009, 113, 202.

(32) Tomé, L. I. N.; Varanda, F. R.; Freire, M. G.; Marrucho, I. M. Coutinho, J. A. P. J. Phys. Chem. B 2009, 113, 2815.
(33) Baker, S. N.; Baker, G. A.; Bright, F. V. Green Chem. 2002, 4 , 165.

(34) Reichardt, C. Chem. Rev. 1994, 94, 2319.

(35) Kamlet, M. J.; Taft, R. W. J. Am. Chem. Soc. 1976, 98, 377.

(36) Aki, S. N. V. K.; Brennecke, J. F.; Samanta, A. Chem. Commun. 2001, 413.

(37) Reichardt, C. Green Chem. 2005, 7, 339.

(38) Lungwitz, R.; Friedrich, M.; Linert, W.; Spange, S. New J. Chem. 2008, 32, 1493.

(39) Huddleston, J. G.; Willauer, H. D.; Rogers, R. D. J. Chem. Eng. Data 2003, 48, 1230.

(40) Yaminsky, V. V.; Vogler, E. A. Curr. Opin. Colloid Interface Sci. 2001, 6, 342 .

(41) Holbrey, J. D.; Reichert, W. M.; Nieuwenhuyzen, M.; Sheppard, O.; Hardacre, C.; Rogers, R. D. Chem. Commun. 2003, 4, 476.

(42) Zhao, H. J. Chem. Technol. Biotechnol. 2006, 81, 877.

(43) Lu, M.; Tjerneld, F. J. Chromatogr. A 1997, 766, 99.

(44) Salabat, A.; Abnosi, M. H.; Motahari, A. J. Chem. Eng. Data 2008, 53, 2018.

JP903286D 